\title{
Updating the role of obesity and cholesterol in breast cancer
}

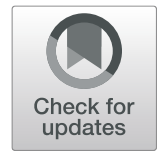

\author{
Laura Garcia-Estevez ${ }^{1 *}$ and Gema Moreno-Bueno ${ }^{1,2}$
}

\begin{abstract}
Background: Breast cancer is the second most common cause of cancer-related death among women. Advances in our understanding of the disease have translated into better diagnostics and more effective therapeutics, leading to earlier detection and improved outcomes. Several studies have pointed at lifestyle and environmental factors as contributory for the onset and progression of the disease. Obesity and cholesterol stand out for their potential causal relationship with breast cancer and ease of modification.

Main text: Obesity and cholesterol represent risk factors for breast cancer, but their impact is largely affected by cofounding variables including menopausal status, disease subtype, and inflammation. Establishing a causal relationship between lifestyle factors and clinical outcomes may be challenging. Epidemiological studies and metaanalyses have rendered conflicting or sometimes contradictory results, possibly owing to the multifactorial nature of the disease. We discuss the supporting evidence and limitations in our understanding of obesity and cholesterol as risk factors for breast cancer.
\end{abstract}

Conclusions: There is sufficient evidence that obesity and cholesterol impact clinical outcomes. Physicians are advised to take steps to help patients with their weight, such as recommending dietary and lifestyle interventions.

Keywords: Lifestyle factors, White adipose tissue, Inflammation, Estrogen, Progesterone, Menopause

\section{Background}

Breast cancer is the most prevalent cancer in women and the second leading cause of cancer death worldwide. In the European Union, an estimated 358.967 new cases and 90.665 breast cancer-related deaths are reported every year [1].

The classification of breast carcinoma relies on clinicopathological features and the expression of estrogen receptor (ER), progesterone receptor (PR), and human epidermal growth factor receptor 2 (HER2). Tumors expressing hormonal receptors constitute the most common breast cancer subtype, accounting for $60-70 \%$ of cases.

Genetic profiling, age of menarche and menopause, parity, age of first child, previous occurrence of cancer, and lifestyle are well-known risk factors for breast cancer. Although the identification of hereditable genetic factors has been critical for our understanding of the disease-and invaluable for providing women with the choice of

\footnotetext{
* Correspondence: Igestevez@mdanderson.es

${ }^{1}$ Breast Cancer Department, MD Anderson Cancer Center, Arturo Soria 270, 280339 Madrid, Spain

Full list of author information is available at the end of the article
}

preventative resection surgery- $B R C A 1 / 2$ mutations account for a small percentage (5-10\%) of cases [2].

Lifestyle is considered an increasingly important contributing factor to breast cancer etiology. Obesity, overweight, metabolic syndrome, alcohol and hypercholesterolemia represent risk factors for breast cancer, whereas regular exercise appears to be protective [3]. However, their role in breast cancer remains largely unknown. Identifying lifestyle factors and understanding their effector mechanisms is paramount for establishing new primary prevention rules for breast cancer.

\section{Obesity, overweight, and breast cancer risk}

Obesity, defined as a body mass index (BMI) of $\geq 30 \mathrm{~kg} / \mathrm{m} 2$, affects over 600 million adults worldwide. The World Health Organization estimates that $40 \%$ of adult women are overweight, with prevalence tripling between 1975 and 2016 [4].

The impact of obesity on breast cancer risk differs across menopausal status and disease subtypes. Current evidence suggests that a high BMI associates with a reduced risk of premenopausal breast cancer, but strongly 
correlates with an increased risk after menopause [5]. Two meta-analyses on premenopausal women with ER+ breast cancer showed an inverse association between BMI and ER-positivity [6, 7]; obesity was more frequent in patients with $\mathrm{ER}-/ \mathrm{PR}$ - than with $\mathrm{ER}+/ \mathrm{PR}+$ tumors (OR, 1.49; 95\%CI, 1.29-1.73; $p=1 \times 10^{-7}$ ). This observation is corroborated by most studies, indicating that obesity associates with a higher risk of breast cancer in premenopausal ER-negative and triple-negative breast cancers (TNBC) $[6,8]$.

Postmenopausal obesity seems to be a risk factor for the onset of hormone receptor-positive breast cancer in postmenopausal women [7, 9-11]. The relationship between BMI and postmenopausal breast cancer appears to be limited to $\mathrm{ER}+/ \mathrm{PR}+(\mathrm{RR}, 1.39 ; 95 \% \mathrm{CI}, 1.14-1.70)$ but not $\mathrm{ER}$ -/PR- (RR, 0.98; 95\%CI, 0.78-1.22) breast cancer [7]. A Women's Health Initiative trial showed that BMI associated with a higher risk of $\mathrm{ER}+$ and $\mathrm{PR}+$ breast cancer, with hazard ratios (HR) increasing with each BMI level (HR, 1.86; $95 \%$ CI, $1.60-2.17$ for $\mathrm{BMI} \geq 35.0$ ) [11]. The Million Women Study in the UK identified a nearly 30\% higher risk of developing postmenopausal breast cancer with obesity (RR, 1.29; 95\%CI, 1.22-1.36) [12]. Likewise, a meta-analysis of 34 studies comprising $>2.5$ million women showed that postmenopausal breast cancer risk positively associates with each $5 \mathrm{~kg} / \mathrm{m} 2$ increase in BMI (RR, 1.12; 95\%CI, 1.08-1.16 [ $p<0.0001]$ ) [13].

An additional concern is the role of weight change across the life course. In this context, a prospective observational study of 74,177 women by Rosner and colleagues [14] indicated that weight loss $>5 \mathrm{~kg}$ since age 18 was inversely associated with risk of postmenopausal breast cancer, whereas weight gain after that age correlated with an increased risk - and the timing of weight gain either before or after menopause did not modify the risk.

\section{Obesity and breast cancer prognosis}

Obesity and overweight have been linked with shorter all-cause and breast cancer survival. Ewertz and colleagues determined that the risk of developing distant metastasis in early-stage breast cancer patients (including ER+, ERand unknown tumors) with a BMI $\geq 30 \mathrm{~kg} / \mathrm{m} 2$ increased by 42 to $46 \%$ after 10 years, compared to patients with a BMI $<25 \mathrm{~kg} / \mathrm{m}^{2}$, and the risk of death due to breast cancer after 30 years was significantly increased by $38 \%$ in patients with a BMI $\geq 30 \mathrm{~kg} / \mathrm{m} 2[15,16]$. A separate study in TNBC patients failed to unequivocally demonstrate an association between obesity and mortality, as opposed to ER-positive women whose risk of death was threefold higher [17]. Furthermore, a meta-analysis of 43 studies reported a HR of $1.33(95 \% \mathrm{CI}, 1.19-1.50)$ for breast cancer-related mortality when contrasting obese and non-obese breast cancer patients [18].
The largest meta-analysis to date on this topic was conducted by Chan et al. comprising 213,075 patients from 82 studies [19]. The authors compared total and breast cancer-specific mortality in obese, overweight, normal-weight, and under-weight patients, before and after diagnosis. Before diagnosis, the summary relative risk (RR) for total mortality and breast cancer-specific mortality were 1.41 (95\%CI, 1.29-1.53) and 1.35 (95\%CI, 1.24-1.47), respectively, for obese vs. normal-weight patients. This positive association remained when BMI was measured within and after 12 months from diagnosis, regardless of menopausal status. The RR for total mortality and breast cancer-specific mortality for overweight vs. normal-weight patients at baseline were lower (1.07 [95\% CI, 1.02-1.12] and 1.11 [95\%CI, 1.06-1.17], respectively), but remained statistically significant [19]. Similar summary risk estimates were obtained when adjusting for confounding factors including tumor stage.

Despite an apparent causal relationship between BMI and survival, data is conflicting when considering breast cancer subtypes. A meta-analysis of 21 studies, analyzing the association between obesity, hormone receptor, and menopausal status [20], reported increased pooled HR for OS in heavier vs. lighter women both in ER+/PR+ and ER-/PR- cancers and in pre- and postmenopausal women groups. However, differences between groups lacked significance $(p=0.31$ and $p=0.57$, respectively), implying that the impact of obesity on breast cancer outcome is independent of hormone receptor or menopausal status. Clearly, prospective studies are required to further elucidate the role of obesity in different disease groups.

A summary of clinical studies investigating the association of obesity with breast cancer is presented in Table 1 .

\section{Obesity, chronic inflammation, and breast cancer}

Excessive caloric intake or reduced caloric expenditure leads to expansion of adipose compartments via hyperplasia and/or adipocyte hypertrophy. These conditions alter the physiology of white adipose tissue (WAT), causing dysregulation in the production of steroid hormones and adipokines, and chronic subclinical inflammation. Such alterations have been linked to carcinogenesis, tumor progression, and metastasis [21].

Adipose tissue inflammation may represent the physiological link between obesity and breast cancer. Inflamed adipose tissue is characterized by infiltrating macrophages encircling dead or dying adipocytes in a configuration termed crown-like structures (CLS) [22]. The presence of CLS in breast adipose tissue (CLS-B) is associated with activation of NF- $\mathrm{kB}$ and increased levels of pro-inflammation factors, resulting in upregulation of estradiol (E2). The upshot is that locally produced estrogens as a result of obesity-related WAT inflammation-axis might represent key drivers 
Table 1 Summary of studies investigating the association of obesity with breast cancer

\begin{tabular}{|c|c|c|c|c|}
\hline Reference & Study type & Treatment & Results & Measure of association \\
\hline $\begin{array}{l}\text { Yang } 2011 \\
{[6]}\end{array}$ & Meta-analysis & n.a. & $\begin{array}{l}\text { Obesity in women } \leq 50 \text { years is more frequent in } \mathrm{ER}(-) / \mathrm{PR}(-) \\
\text { tumors } \\
\text { Obesity in women }>50 \text { years is less frequent in } \mathrm{ER}(-) \text { tumors }\end{array}$ & $\begin{array}{l}p=1 \times 10^{-7} \\
p=6 \times 10^{-4}\end{array}$ \\
\hline $\begin{array}{l}\text { Munsell } \\
2014[7]\end{array}$ & Meta-analysis & Estrogen-progestin & $\begin{array}{l}\text { Obesity associates with risk of hormone receptor-positive } \\
\text { breast cancer: Premenopausal } \\
\text { Postmenopausal }\end{array}$ & $\begin{array}{l}\mathrm{RR}, 0.78 ; 95 \% \mathrm{Cl}, 0.67-0.92 \\
\mathrm{RR}, 1.39 ; 95 \% \mathrm{Cl}, 1.14-1.70\end{array}$ \\
\hline $\begin{array}{l}\text { Pierobom } 2013 \\
\text { [8] }\end{array}$ & Meta-analysis & n.a. & $\begin{array}{l}\text { Obesity associates with TNBC tumors in premenopausal } \\
\text { women }\end{array}$ & $\mathrm{OR}, 1.43 ; 95 \% \mathrm{Cl}, 1.23-1.65$ \\
\hline $\begin{array}{l}\text { Enger } 2000 \\
{[62]}\end{array}$ & $\begin{array}{l}\text { Case-case/ } \\
\text { case-control }\end{array}$ & n.a. & $\begin{array}{l}\text { Obesity associates with } \mathrm{ER}(+) / \mathrm{PR}(+) \text { in postmenopausal } \\
\text { women }\end{array}$ & $\mathrm{OR}, 2.45 ; 95 \% \mathrm{Cl}, 1.73-3.47$ \\
\hline $\begin{array}{l}\text { Rosenberg } \\
2006 \text { [63] }\end{array}$ & Population-based & $\begin{array}{l}\text { Estrogen alone } \\
\text { Estrogen-progestin }\end{array}$ & $\begin{array}{l}\text { Weight gain }>30 \mathrm{~kg} \text { in adulthood associates with risk } \\
\text { of } \mathrm{ER}(+) / \mathrm{PR}(+) \text { tumors }\end{array}$ & $\mathrm{OR}, 1.5 ; 95 \% \mathrm{Cl}, 1.2-1.8$ \\
\hline $\begin{array}{l}\text { Nagrani } \\
2016[9]\end{array}$ & Case-control & $\begin{array}{l}\text { HRT patients } \\
\text { excluded }\end{array}$ & $\begin{array}{l}\text { Premenopausal women with a } \mathrm{BMI} \geq 30 \text { are at lower risk } \\
\text { of breast cancer } \\
\text { Women postmenopausal for } \geq 10 \text { years are at higher risk } \\
\text { of breast cancer }\end{array}$ & $\begin{array}{l}\text { OR, } 0.5 ; 95 \% \mathrm{Cl}, 0.4-0.8 \\
\text { OR, } 1.8 ; 95 \% \mathrm{Cl}, 1.1-3.3\end{array}$ \\
\hline $\begin{array}{l}\text { Suzuki } 2006 \\
{[64]}\end{array}$ & Population-based & $\begin{array}{l}\text { Oral } \\
\text { contraceptives } \\
\text { Postmenopausal } \\
\text { hormones }\end{array}$ & $\begin{array}{l}\text { Obesity associates with risk of developing } \mathrm{ER}(+) / \mathrm{ER}(+) \\
\text { tumors in postmenopausal women }\end{array}$ & $\mathrm{RR}, 1.67,95 \% \mathrm{Cl}, 1.34-2.07$ \\
\hline Ahn 2007 [10] & Prospective & $\begin{array}{l}\text { Postmenopausal } \\
\text { hormones }\end{array}$ & $\begin{array}{l}\text { Weight gain after age } 18 \text { associates with postmenopausal } \\
\text { breast cancer risk in menopausal hormone therapy non-users }\end{array}$ & $\mathrm{RR}, 2.15,95 \% \mathrm{Cl}, 1.35-3.42$ \\
\hline $\begin{array}{l}\text { Neuhouser } \\
2015 \text { [11] }\end{array}$ & Randomized & $\begin{array}{l}\text { Postmenopausal } \\
\text { hormones }\end{array}$ & $\begin{array}{l}\text { Obesity and overweight associate with increased risk of invasive } \\
\text { breast cancer } 5 \% \text { body weight gain in women with BMI } \\
<25 \text { associates with increased breast cancer risk }\end{array}$ & $\begin{array}{l}\mathrm{HR}, 1.58 ; 95 \% \mathrm{Cl}, 1.40-1.79 \\
\mathrm{HR}, 1.36 ; 95 \% \mathrm{Cl}, 1.1-1.65\end{array}$ \\
\hline $\begin{array}{l}\text { Reeves } \\
2007 \text { [12] }\end{array}$ & Prospective & HRT & $\begin{array}{l}\text { Increasing BMI associates with increasing incidence of breast } \\
\text { cancer in postmenopausal women }\end{array}$ & $\mathrm{RR}, 1.40 ; 95 \% \mathrm{Cl}, 1.31-1.49$ \\
\hline
\end{tabular}

n.a not available, HRT hormone replacement therapy

for hormone-dependent breast cancer development in postmenopausal women (Fig. 1).

Iyengar and collaborators provided the first evidence that postmenopausal women have larger adipocytes and greater prevalence and severity of WAT inflammation in the breast [23]. Strikingly, 90\% of obese women had CLS-B. Breast WAT inflammation at diagnosis is associated with a 6-month shorter distant relapse-free survival (dRFS) in women who developed metastatic disease; results remained significant when adjusting for prognostic factors including BMI.

Adipocytes produce adiponectin and leptin, which participate in the regulation of caloric intake and metabolism, inflammation, angiogenesis, and cell proliferation. Breast cancer cells are surrounded and influenced by this microenvironment. Leptin appears to be strongly involved in mammary carcinogenesis and may contribute to the local pro-inflammatory mechanisms, especially in obese patients. There is a positive correlation between BMI index and leptin levels, whereas adiponectin concentrations generally decrease with greater adiposity (Fig. 1). The increased leptin-adiponectin ratio seen in obesity has been implicated in neoplastic transformation and tumor progression [24].
Leptin may act as a molecular link between obesity and breast cancer [25]. Breast cancer cells overexpress leptin receptor, hence becoming highly susceptible to the influence of elevated leptin levels typically seen in obese patients [26]. Leptin displays pleiotropic effects that include inhibition of pro-apoptotic signals in breast cancer cells, sensitization to estrogens, and modulation of the tumor microenvironment, contributing to local pro-inflammatory mechanisms and promoting mammary tumor growth (Fig. 1) [27, 28]. Increased leptin levels in breast cancer patients have been linked with risk of metastasis and reduced survival [26]. Niu and collaborators conducted a meta-analysis including pre- and postmenopausal breast cancer women and healthy controls, as well as lymph node metastasis positive cases, and concluded that leptin levels play a role in breast cancer [29].

\section{Cholesterol and breast cancer risk}

High blood cholesterol is a common comorbidity in obesity [30]. Its impact as a risk factor for breast cancer is conflicting, and it is unclear whether total, LDL, or HDL cholesterol contribute to the disease [31]. It is important to differentiate the association between total cholesterol and breast cancer risk, and the role of high-fat diet for disease onset. Moreover caution is needed when interpreting 


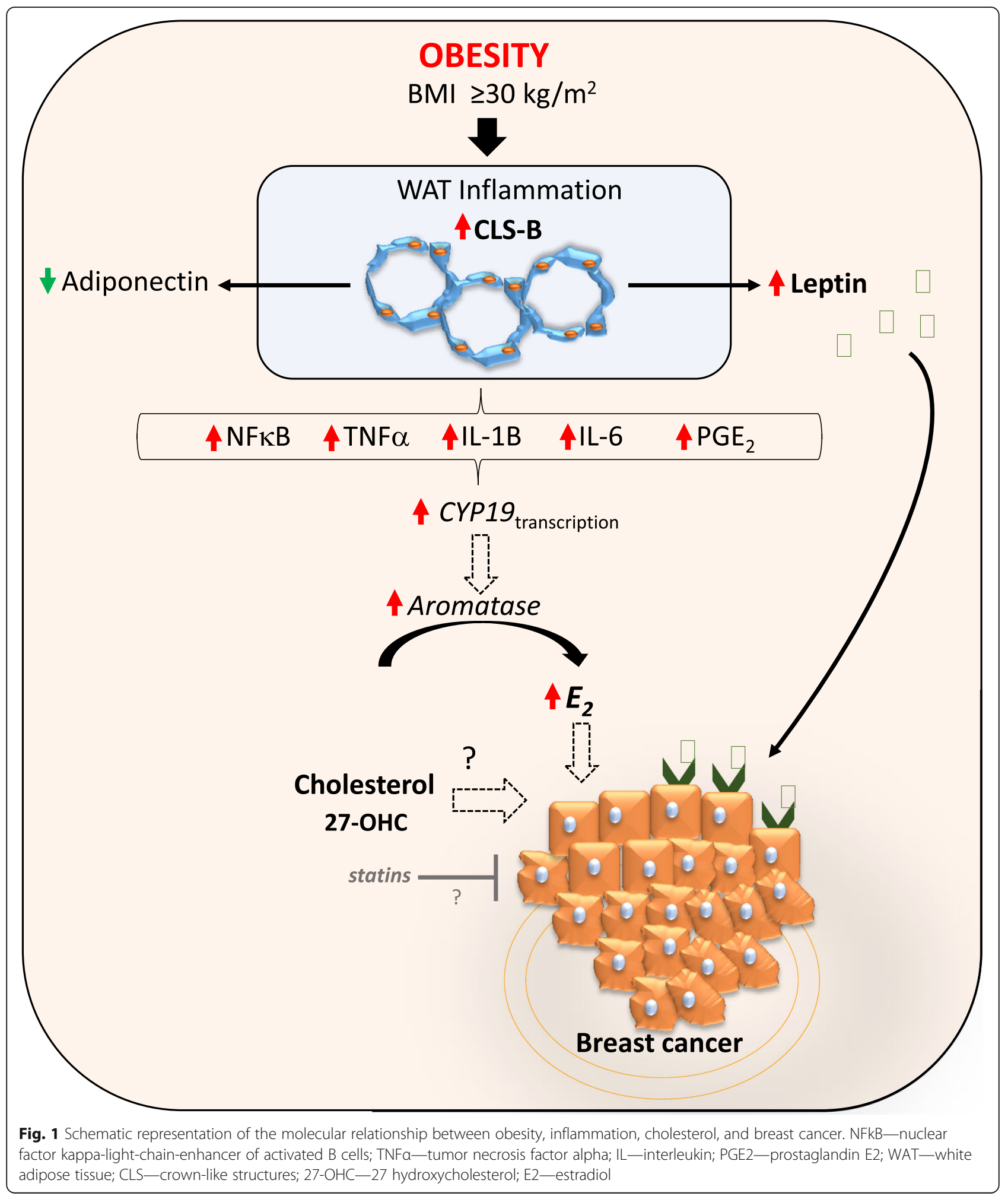

results, as blood cholesterol levels may be influenced by different cancer mechanisms [32].

Touvier and collaborators conducted the first systematic review and meta-analysis of prospective studies investigating the association between total cholesterol
(TC), HDL-C, LDL-C, ApoA1, and ApoB with breast cancer risk [33]. Their analysis suggested a modest but statistically significant inverse association between pre-diagnostic total cholesterol levels (dose-response HR, 0.94; 95\%CI 0.89-0.99, seven studies, $I^{2}=78 \%$; 
highest vs. lowest HR, 0.82; 95\%CI 0.66-1.02; nine studies, $I^{2}=81 \%$ ) and HDL-C levels (dose-response HR, 0.81 ; 95\%CI 0.65-1.02, five studies, $I^{2}=30 \%$; highest vs. lowest HR, 0.82; 95\%CI 0.69-0.98, five studies, $I^{2}=0 \%$ ) with breast cancer risk [33].

A recent prospective study investigating the association between pre-diagnostic serum lipid concentrations and breast cancer risk and survival reported that, overall, serum lipids did associate with breast cancer risk, regardless of BMI and tumor ER status or when accounting for time between blood collection and diagnosis [34]. By contrast, a large study in over 664,000 women utilizing Big Data from the UK Algorithm for Co-morbidity, Associations, Length of Stay and Mortality (ACALM) registry found an association between hyperlipidemia and breast cancer. The ACALM study demonstrated that women above 40 with high cholesterol were $45 \%$ less likely to develop breast cancer than those without high cholesterol [35]. Of the patients who developed breast cancer, those with high cholesterol had a $40 \%$ lower risk of death [35]. The authors concluded that women with high cholesterol have strikingly lower rates of breast cancer and improved survival outcomes. One potential explanation for these findings is that the use of statins to lower cholesterol levels may reduce the risk of breast cancer, breast cancer recurrence, and mortality rates [36]. However, evidence from several meta-analyses for the protective effect of statins in breast cancer is nowadays conflicting $[37,38]$.

A large prospective trial of postmenopausal women evaluated the association between serum total cholesterol and breast cancer risk taking BMI into account [39]. In an age-adjusted model, there was a positive association between cholesterol levels and breast cancer (p-trend, 0.0024); however, the association lost significance when adjusting for BMI (p-trend, 0.0684).

\section{7-Hydroxycholesterol and breast cancer}

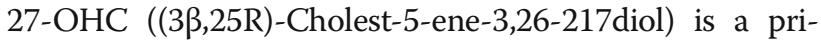
mary metabolite of cholesterol hydroxylation mediated by CYP27A1 and circulates at comparable or slightly higher concentrations compared to other oxyteroles [40].

In models of cardiovascular disease, 27-OHC behaves as an ER antagonist, while in osteoblasts and cellular models of ER-positive breast cancer it functions as a partial ER agonist [41]. Based on these and other reports, $27-\mathrm{OHC}$ is now considered an endogenously produced selective estrogen receptor modulator (SERM) [42].

SERMs modulate the activity of ER in a context-specific manner. Importantly, therapeutic use of SERMs significantly reduces the incidence of breast cancer [43]. The best characterized SERM is tamoxifen, which acts as an ER antagonist [44]. Intra-tumor levels of $27-\mathrm{OHC}$ are sixfold higher in ER-positive breast tumors relative to the adjacent normal tissue [45] and act as a partial agonist in cell models of ER-positive breast cancer, stimulating their proliferation [46]. It has been hypothesized that 27-OHC rather than cholesterol per se is responsible for stimulating the proliferation of ER-positive breast cancer cells. Indeed, exogenous administration of $27-\mathrm{OHC}$ promotes the growth of MCF7 xenografts, and the effect is reversed by co-treatment with ER antagonists [44].

27-OHC also has activity as a liver X receptor (LXR) agonist. LXR activation typically results in inhibition of cell proliferation secondary to cellular cholesterol efflux [47]. Co-activation of ER and LXR results in competitive intracellular signaling and cross-modulation, as demonstrated by loss-of-function in vitro experiments whereby $27-\mathrm{OHC}$ activity on LXR-knocked-down cells enhanced the induction of ER target genes, whereas in ER-knocked-down cells resulted in significant up-regulation of LXR target genes [48]. In ER-positive breast cancer cells, the "ER-activity" of 27-OHC prevails over the growth inhibitory action of LXRs; however, the extent of these activities may be fine-tuned by cellular and microenvironmental cues impinging on either the LXR or ER axes.

Several studies have suggested an association between 27-OHC and serum cholesterol [49, 50]. Considering the role of $27-\mathrm{OHC}$ in stimulating tumor growth in in vitro models of ER+ breast cancer, $\mathrm{Lu}$ and collaborators explored the association between $27 \mathrm{HC}$ and breast cancer risk in a nested case-control study, using the European Prospective Investigation into Cancer and Nutrition (EPIC)-Heidelberg cohort [51]. Although 27HC was not associated with breast cancer risk overall, the study identified that the association between $27 \mathrm{HC}$ levels and breast cancer risk differed by menopausal status at blood collection; whilst no relationship was observed among premenopausal women, postmenopausal women at blood collection had a statistically significant inverse association between $27 \mathrm{HC}$ levels and breast cancer risk. The authors considered that the "benefit" of 27HC-mediated inhibition of estradiol-ER binding outweighs the "harm" of the partial agonistic effect of $27 \mathrm{HC}$ in breast cancer. These results warranty additional experimental studies on the combined effects of estradiol and 27HC.

Few known breast cancer risk factors exhibit opposing effects in pre- and postmenopausal women. Apart from BMI, which has been covered in the previous section, and of circulating $27 \mathrm{HC}$ levels as reported above, further studies in well-characterized populations, including preand postmenopausal women at diagnosis and at blood collection, are required to confirm these findings.

Given the association between high cholesterol and worse prognosis, and of statin usage with shorter recurrence-free survival [52], there is significant interest in the potential benefit of cholesterol-lowering medication in breast cancer patients. In the Breast International Group 
1-98 study [53], patients initiating cholesterol-lowering medication in combination with standard endocrine therapy demonstrated longer disease-free survival, breast cancer-free interval, and distant recurrence-free interval.

\section{Dietary cholesterol intake/fat intake and breast cancer risk} Generally, dietary saturated fat intake is synonym of dietary cholesterol intake. It is well established that saturated fat raises low-density lipoprotein (LDL) cholesterol, a leading cause of atherosclerosis and cardiovascular disease [54]. Saturated fat is found in animal foods such as red meat, poultry, and full- or reduced-fat dairy products.

$\mathrm{Li}$ and collaborators conducted the first meta-analysis examining the association between dietary cholesterol and breast cancer [55]. The pooled RR for the highest (median $394 \mathrm{mg} /$ day) vs. the lowest (median $138 \mathrm{mg} /$ day) dietary cholesterol categories was 1.29 (1.06-1.56). For dose-response analysis, a nonlinear association was found between dietary cholesterol and breast cancer; and the association became significant when the cholesterol consumption was greater than $370 \mathrm{mg} /$ day.

These results strongly suggest an association of dietary cholesterol and breast cancer. By contrast, some epidemiological studies have failed to reach similar conclusions or have restricted the impact to specific groups of patients [56, 57] (Table 2).

The Mediterranean diet is a good example of a low-fat diet. It is characterized by a high intake of virgin olive oil, vegetables, fruits, plant proteins, fish and other seafood, whole grains, nuts, and low-fat dairy, accompanied by moderate alcohol intake and low red meat consumption [58]. The beneficial effects of a Mediterranean diet have been noted with regards to decreasing the risk of breast cancer and breast cancer recurrence, while improving overall survival [59-61].

\section{Conclusion}

Overweight and obesity are intimately related with breast cancer development and recurrence. The interplay between obesity, inflammation, and the tumor microenvironment drive tumor expansion, primarily in hormone-sensitive and postmenopausal patients. Lately, the role of leptin and leptin receptor in breast cancer cells has shed light on the role of the adipose environment in breast cancer.

Several meta-analyses have provided evidence that obesity carries a $35-40 \%$ increased risk of recurrence and death, irrespective of menopausal or hormone receptor status. In this regard, breast cancer prevention

Table 2 Summary of clinical studies investigating the association of cholesterol with breast cancer

\begin{tabular}{|c|c|c|c|}
\hline Reference & Study type & Results & Measure of association* \\
\hline Touvier 2015 [33] & Meta-analysis & $\begin{array}{l}\text { Cholesterol associates with a reduced risk of breast cancer: } \\
\text { total cholesterol (dose response) } \\
\text { Total cholesterol (highest vs. lowest) } \\
\text { HDL-C (dose-response) } \\
\text { HDL-C (highest vs. lowest) }\end{array}$ & $\begin{array}{l}H R, 0.94 ; 95 \% \mathrm{Cl}, 0.89-0.99 \\
\mathrm{HR}, 0.82 ; 95 \% \mathrm{Cl}, 0.66-1.02 \\
\mathrm{HR}, 0.81 ; 95 \% \mathrm{Cl}, 0.65-1.02 \\
H R \quad 0.82 ; 95 \% \mathrm{Cl}, 0.69-0.98\end{array}$ \\
\hline Bahl 2005 [52] & Prospective & $\begin{array}{l}\text { Higher total cholesterol associates with a trend towards } \\
\text { increased risk of recurrence }\end{array}$ & $p=0.03$ \\
\hline Carter 2017 [35] & Retrospective & Hyperlipidaemia associates with a reduced risk of breast cancer & $\mathrm{OR}, 0.67 ; 95 \% \mathrm{Cl}, 0.48-0.92$ \\
\hline Ha 2009 [39] & Retrospective & $\begin{array}{l}\text { Positive association between cholesterol levels and breast cancer: } \\
\text { In postmenopausal women (age-adjusted model) } \\
\text { In postmenopausal women after adjusting for BMI }\end{array}$ & $\begin{array}{l}p \text {-trend }=0.0024 \\
p \text {-trend }=0.0684\end{array}$ \\
\hline Borgquist 2017 [53] & Phase III & $\begin{array}{l}\text { Cholesterol-lowering medication associates with improved: } \\
\text { Disease-free-survival } \\
\text { Breast cancer-free interval } \\
\text { Distant recurrence-free interval }\end{array}$ & $\begin{array}{l}H R, 0.79 ; 95 \% \mathrm{Cl}, 0.66-0.95 \\
H R, 0.76 ; 95 \% \mathrm{Cl}, 0.60-0.97 \\
H R, 0.74 ; 95 \% \mathrm{Cl}, 0.56-0.97\end{array}$ \\
\hline Li 2016 [55] & Meta-analysis & Dietary cholesterol associates with increased risk of breast cancer & $R R, 1.29 ; 95 \% C l, 1.06-1.56$ \\
\hline Hu 2012 [57] & Population-based & $\begin{array}{l}\text { Association of high cholesterol intake with risk of breast cancer: } \\
\text { Postmenopausal women } \\
\text { Premenopausal women }\end{array}$ & $\begin{array}{l}\mathrm{OR}, 1.48 ; 95 \% \mathrm{Cl}, 1.07-2.07 \\
\mathrm{OR}, 1.10 ; 95 \% \mathrm{Cl}, 0.75-1.72\end{array}$ \\
\hline Undela 2012 [65] & $\begin{array}{l}\text { Meta-analysis } \\
\text { (observational studies) }\end{array}$ & $\begin{array}{l}\text { Statin use does not significantly impact breast cancer risk } \\
\text { Long-term statin use does not significantly impact breast } \\
\text { cancer risk }\end{array}$ & $\begin{array}{l}\mathrm{RR}, 0.99 ; 95 \% \mathrm{Cl}, 0.94-1.04 \\
\mathrm{RR}, 1.03 ; 95 \% \mathrm{Cl}, 0.96-1.11\end{array}$ \\
\hline Mansourian 2016 [66] & $\begin{array}{l}\text { Meta-analysis } \\
\text { (observational studies) }\end{array}$ & $\begin{array}{l}\text { Statin use associates with reduced: } \\
\text { Breast cancer recurrence } \\
\text { Breast cancer mortality }\end{array}$ & $\begin{array}{l}\text { OR, } 0.79 ; 95 \% \mathrm{Cl}, 0.73-0.85 \\
\text { OR, } 0.84 ; 95 \% \mathrm{Cl}, 0.82-0.87\end{array}$ \\
\hline Islam 2017 [38] & $\begin{array}{l}\text { Meta-analysis } \\
\text { (observational studies) }\end{array}$ & Statin use does not associate with reduced breast cancer risk & $\mathrm{RR}, 0.94 ; 95 \% \mathrm{Cl}, 0.86-1.03$ \\
\hline
\end{tabular}


requires raising awareness among women for watching their body weight, especially those in menopause. This can be achieved through a low-cholesterol/low-saturated fat diet and regular exercise.

The role of total blood cholesterol for breast cancer development is controversial. Most studies show that high cholesterol levels prior to diagnosis protect against the development of tumors, prompting some authors to advocate the use of statins to lower cholesterol. It is uncertain that total cholesterol makes the most appropriate risk biomarker, with 27-OHC perhaps a more suitable candidate.

Collectively, clinical studies and meta-analyses support a role for obesity, dietary fat intake and/or cholesterol in the onset and progression of the disease, and practicing physicians should be pro-active in recommending habits such as an appropriate diet and regular physical activity to maintain a healthy weight.

\section{Acknowledgements}

The authors thank the members of the translational cancer research laboratory at the MD Anderson Cancer Center Foundation.

\section{Funding}

This work was supported by grants from the Instituto de Salud Carlos III (ISCIII) and FEDER (PI16/00134 and CIBERONC CB16/12/00295).

\section{Availability of data and materials}

N/A.

\section{Authors' contributions}

LGE and GMB conceived, wrote, and approved the final article.

\section{Ethics approval and consent to participate}

N/A

\section{Consent for publication}

N/A.

\section{Competing interests}

The authors declare that they have no competing interests.

\section{Publisher's Note}

Springer Nature remains neutral with regard to jurisdictional claims in published maps and institutional affiliations.

\footnotetext{
Author details

${ }^{1}$ Breast Cancer Department, MD Anderson Cancer Center, Arturo Soria 270, 280339 Madrid, Spain. ${ }^{2}$ Biochemistry Department, Universidad Autónoma de Madrid (UAM), Instituto de Investigaciones Biomédicas 'Alberto Sols' (CSIC-UAM), IdiPaz, \& Centro de Investigación Biomédica en Red de Cáncer (CIBERONC), Madrid, Spain.
}

Published online: 01 March 2019

\section{References}

1. Ferlay J, Steliarova-Foucher E, Lortet-Tieulent J, Rosso S, Coebergh JW, Comber $H$, Forman D, Bray F. Cancer incidence and mortality patterns in Europe: estimates for 40 countries in 2012. Eur J Cancer. 2013;49(6):1374-403.

2. Shah R, Rosso K, Nathanson SD. Pathogenesis, prevention, diagnosis and treatment of breast cancer. World J Clin Oncol. 2014;5(3):283-98.

3. Jones LW, Fels DR, West M, Allen JD, Broadwater G, Barry WT, Wilke LG, Masko E, Douglas PS, Dash RC, et al. Modulation of circulating angiogenic factors and tumor biology by aerobic training in breast cancer patients receiving neoadjuvant chemotherapy. Cancer Prev Res (Phila). 2013;6(9):925-37.
4. Obesity and overweight [http://www.who.int/news-room/fact-sheets/detail/ obesity-and-overweight]. Accessed 26 Feb 2019.

5. Kerr J, Anderson C, Lippman SM. Physical activity, sedentary behaviour, diet, and cancer: an update and emerging new evidence. Lancet Oncol. 2017; 18(8):e457-71.

6. Yang XR, Chang-Claude J, Goode EL, Couch FJ, Nevanlinna H, Milne RL, Gaudet M, Schmidt MK, Broeks A, Cox A, et al. Associations of breast cancer risk factors with tumor subtypes: a pooled analysis from the Breast Cancer Association Consortium studies. J Natl Cancer Inst. 2011;103(3):250-63.

7. Munsell MF, Sprague BL, Berry DA, Chisholm G, Trentham-Dietz A. Body mass index and breast cancer risk according to postmenopausal estrogenprogestin use and hormone receptor status. Epidemiol Rev. 2014;36:114-36.

8. Pierobon M, Frankenfeld CL. Obesity as a risk factor for triple-negative breast cancers: a systematic review and meta-analysis. Breast Cancer Res Treat. 2013;137(1):307-14.

9. Nagrani R, Mhatre S, Rajaraman P, Soerjomataram I, Boffetta P, Gupta S, Parmar V, Badwe R, Dikshit R. Central obesity increases risk of breast cancer irrespective of menopausal and hormonal receptor status in women of South Asian Ethnicity. Eur J Cancer. 2016;66:153-61.

10. Ahn J, Schatzkin A, Lacey JV Jr, Albanes D, Ballard-Barbash R, Adams KF, Kipnis V, Mouw T, Hollenbeck AR, Leitzmann MF. Adiposity, adult weight change, and postmenopausal breast cancer risk. Arch Intern Med. 2007; 167(19):2091-102.

11. Neuhouser ML, Aragaki AK, Prentice RL, Manson JE, Chlebowski R, Carty CL, Ochs-Balcom HM, Thomson CA, Caan BJ, Tinker LF, et al. Overweight, obesity, and postmenopausal invasive breast cancer risk: a secondary analysis of the Women's Health Initiative Randomized Clinical Trials. JAMA Oncol. 2015;1(5):611-21.

12. Reeves GK, Pirie K, Beral V, Green J, Spencer E, Bull D, Million Women Study C. Cancer incidence and mortality in relation to body mass index in the Million Women Study: cohort study. BMJ. 2007;335(7630):1134.

13. Renehan AG, Roberts DL, Dive C. Obesity and cancer: pathophysiological and biological mechanisms. Arch Physiol Biochem. 2008;114(1):71-83.

14. Rosner B, Eliassen AH, Toriola AT, Chen WY, Hankinson SE, Willett WC Berkey CS, Colditz GA. Weight and weight changes in early adulthood and later breast cancer risk. Int J Cancer. 2017;140(9):2003-14.

15. Ewertz M, Gray KP, Regan MM, Ejlertsen B, Price KN, Thurlimann B, Bonnefoi $\mathrm{H}$, Forbes JF, Paridaens RJ, Rabaglio M, et al. Obesity and risk of recurrence or death after adjuvant endocrine therapy with letrozole or tamoxifen in the breast international group 1-98 trial. J Clin Oncol. 2012;30(32):3967-75.

16. Ewertz M, Jensen MB, Gunnarsdottir KA, Hojris I, Jakobsen EH, Nielsen D, Stenbygaard LE, Tange UB, Cold S. Effect of obesity on prognosis after earlystage breast cancer. J Clin Oncol. 2011;29(1):25-31.

17. Mei L, He L, Song Y, Lv Y, Zhang L, Hao F, Xu M. Association between obesity with disease-free survival and overall survival in triple-negative breast cancer: a meta-analysis. Medicine (Baltimore). 2018;97(19):e0719.

18. Protani M, Coory M, Martin JH. Effect of obesity on survival of women with breast cancer: systematic review and meta-analysis. Breast Cancer Res Treat. 2010;123(3):627-35.

19. Chan DS, Vieira AR, Aune D, Bandera EV, Greenwood DC, McTiernan A, Navarro Rosenblatt D, Thune I, Vieira R, Norat T. Body mass index and survival in women with breast cancer-systematic literature review and metaanalysis of 82 follow-up studies. Ann Oncol. 2014;25(10):1901-14.

20. Niraula S, Ocana A, Ennis M, Goodwin PJ. Body size and breast cancer prognosis in relation to hormone receptor and menopausal status: a metaanalysis. Breast Cancer Res Treat. 2012;134(2):769-81.

21. Hursting SD, Dunlap SM. Obesity, metabolic dysregulation, and cancer: a growing concern and an inflammatory (and microenvironmental) issue. Ann N Y Acad Sci. 2012;1271:82-7.

22. Cinti S, Mitchell G, Barbatelli G, Murano I, Ceresi E, Faloia E, Wang S, Fortier M, Greenberg AS, Obin MS. Adipocyte death defines macrophage localization and function in adipose tissue of obese mice and humans. J Lipid Res. 2005;46(11):2347-55.

23. lyengar NM, Morris PG, Zhou XK, Gucalp A, Giri D, Harbus MD, Falcone DJ, Krasne MD, Vahdat LT, Subbaramaiah K, et al. Menopause is a determinant of breast adipose inflammation. Cancer Prev Res (Phila). 2015;8(5):349-58.

24. Housa D, Housova J, Vernerova Z, Haluzik M. Adipocytokines and cancer. Physiol Res. 2006;55(3):233-44.

25. Barone I, Giordano C, Bonofiglio D, Ando S, Catalano S. Leptin, obesity and breast cancer: progress to understanding the molecular connections. Curr Opin Pharmacol. 2016;31:83-9. 
26. Ishikawa M, Kitayama J, Nagawa H. Enhanced expression of leptin and leptin receptor (OB-R) in human breast cancer. Clin Cancer Res. 2004;10(13):4325-31.

27. Delort L, Rossary A, Farges MC, Vasson MP, Caldefie-Chezet F. Leptin, adipocytes and breast cancer: focus on inflammation and anti-tumor immunity. Life Sci. 2015;140:37-48.

28. Frankenberry KA, Skinner H, Somasundar P, McFadden DW, Vona-Davis LC. Leptin receptor expression and cell signaling in breast cancer. Int J Oncol. 2006;28(4):985-93.

29. Niu J, Jiang L, Guo W, Shao L, Liu Y, Wang L. The association between leptin level and breast cancer: a meta-analysis. PLoS One. 2013;8(6):e67349

30. Must A, Spadano J, Coakley EH, Field AE, Colditz G, Dietz WH. The disease burden associated with overweight and obesity. JAMA. 1999;282(16):1523-9.

31. Nelson ER, Chang CY, McDonnell DP. Cholesterol and breast cancer pathophysiology. Trends Endocrinol Metab. 2014;25(12):649-55.

32. Law MR, Thompson SG. Low serum cholesterol and the risk of cancer: an analysis of the published prospective studies. Cancer Causes Control. 1991; 2(4):253-61.

33. Touvier M, Fassier P, His M, Norat T, Chan DS, Blacher J, Hercberg S, Galan P, Druesne-Pecollo N, Latino-Martel P. Cholesterol and breast cancer risk: a systematic review and meta-analysis of prospective studies. Br J Nutr. 2015; 114(3):347-57.

34. His M, Dartois L, Fagherazzi G, Boutten A, Dupre T, Mesrine S, BoutronRuault MC, Clavel-Chapelon F, Dossus L. Associations between serum lipids and breast cancer incidence and survival in the E3N prospective cohort study. Cancer Causes Control. 2017;28(1):77-88.

35. Carter PR, Uppal H, Chandran KR, Bainei KR, Potluri R. Patients with a diagnosis of hyperlipidaemia have a reduced risk of developing breast cancer and lower mortality rates: a large retrospective longitudinal cohort study from the UK ACALM registry. Eur Heart J. 2017;38(Suppl 1); 644.

36. Zhong S, Zhang X, Chen L, Ma T, Tang J, Zhao J. Statin use and mortality in cancer patients: systematic review and meta-analysis of observational studies. Cancer Treat Rev. 2015;41(6):554-67.

37. Wu QJ, Tu C, Li YY, Zhu J, Qian KQ, Li WJ, Wu L: Statin use and breast cancer survival and risk: a systematic review and meta-analysis. Oncotarget 2015, 6(40):42988-43004

38. Islam MM, Yang HC, Nguyen PA, Poly TN, Huang CW, Kekade S, Khalfan AM, Debnath T, Li YJ, Abdul SS. Exploring association between statin use and breast cancer risk: an updated meta-analysis. Arch Gynecol Obstet. 2017; 296(6):1043-53.

39. Ha M, Sung J, Song YM. Serum total cholesterol and the risk of breast cancer in postmenopausal Korean women. Cancer Causes Control. 2009; 20(7):1055-60

40. Prunet C, Petit JM, Ecarnot-Laubriet A, Athias A, Miguet-Alfonsi C, Rohmer JF, Steinmetz E, Neel D, Gambert P, Lizard G. High circulating levels of 7beta- and 7alpha-hydroxycholesterol and presence of apoptotic and oxidative markers in arterial lesions of normocholesterolemic atherosclerotic patients undergoing endarterectomy. Pathol Biol (Paris). 2006;54(1):22-32.

41. DuSell CD, Nelson ER, Wang X, Abdo J, Modder UI, Umetani M, GestyPalmer D, Javitt NB, Khosla S, McDonnell DP. The endogenous selective estrogen receptor modulator 27-hydroxycholesterol is a negative regulator of bone homeostasis. Endocrinology. 2010;151(8):3675-85.

42. Nelson ER. The significance of cholesterol and its metabolite, 27hydroxycholesterol in breast cancer. Mol Cell Endocrinol. 2018;466:73-80.

43. Mirkin S, Pickar JH. Selective estrogen receptor modulators (SERMs): a review of clinical data. Maturitas. 2015;80(1):52-7.

44. Nelson ER, Wardell SE, Jasper JS, Park S, Suchindran S, Howe MK, Carver NJ, Pillai RV, Sullivan PM, Sondhi V, et al. 27-Hydroxycholesterol links hypercholesterolemia and breast cancer pathophysiology. Science. 2013; 342(6162):1094-8.

45. Wu Q, Ishikawa T, Sirianni R, Tang H, McDonald JG, Yuhanna IS, Thompson B, Girard L, Mineo C, Brekken RA, et al. 27-hydroxycholesterol promotes cellautonomous, ER-positive breast cancer growth. Cell Rep. 2013;5(3):637-45.

46. DuSell CD, Umetani M, Shaul PW, Mangelsdorf DJ, McDonnell DP. 27hydroxycholesterol is an endogenous selective estrogen receptor modulator. Mol Endocrinol. 2008;22(1):65-77.

47. Baek AE, Nelson ER. The contribution of cholesterol and its metabolites to the pathophysiology of breast cancer. Horm Cancer. 2016;7(4):219-28.

48. Nelson ER, DuSell CD, Wang X, Howe MK, Evans G, Michalek RD, Umetani M, Rathmell JC, Khosla S, Gesty-Palmer D, et al. The oxysterol, 27hydroxycholesterol, links cholesterol metabolism to bone homeostasis through its actions on the estrogen and liver $X$ receptors. Endocrinology. 2011;152(12):4691-705

49. Borgquist S, Bjarnadottir O, Kimbung S, Ahern TP. Statins: a role in breast cancer therapy? J Intern Med. 2018;284(4):346-57.

50. Kimbung S, Chang CY, Bendahl PO, Dubois L, Thompson JW, McDonnell DP, Borgquist S. Impact of 27-hydroxylase (CYP27A1) and 27-hydroxycholesterol in breast cancer. Endocr Relat Cancer. 2017;24(7):339-49.

51. Lu DL, Le Cornet C, Sookthai D, Johnson TS, Kaaks R, Fortner RT. Circulating 27-hydroxycholesterol and breast cancer risk: results from the EPICHeidelberg Cohort. J Natl Cancer Inst. 2018;

52. Bahl M, Ennis M, Tannock IF, Hux JE, Pritchard Kl, Koo J, Goodwin PJ. Serum lipids and outcome of early-stage breast cancer: results of a prospective cohort study. Breast Cancer Res Treat. 2005;94(2):135-44.

53. Borgquist S, Giobbie-Hurder A, Ahern TP, Garber JE, Colleoni M, Lang I, Debled M, Ejlertsen B, von Moos R, Smith I, et al. Cholesterol, cholesterollowering medication use, and breast cancer outcome in the BIG 1-98 study. J Clin Oncol. 2017;35(11):1179-88.

54. Mensink RP, Sanders TA, Baer DJ, Hayes KC, Howles PN, Marangoni A. The increasing use of interesterified lipids in the food supply and their effects on health parameters. Adv Nutr. 2016;7(4):719-29.

55. Li C, Yang L, Zhang D, Jiang W. Systematic review and meta-analysis suggest that dietary cholesterol intake increases risk of breast cancer. Nutr Res. 2016;36(7):627-35.

56. Kuzu OF, Noory MA, Robertson GP. The role of cholesterol in cancer. Cancer Res. 2016;76(8):2063-70.

57. Hu J, La Vecchia C, de Groh M, Negri E, Morrison H, Mery L. Canadian Cancer registries epidemiology research $\mathrm{G}$ : dietary cholesterol intake and cancer. Ann Oncol. 2012;23(2):491-500.

58. Schwingshackl L, Schwedhelm C, Galbete C, Hoffmann G. Adherence to Mediterranean diet and risk of cancer: an updated systematic review and meta-analysis. Nutrients. 2017;9(10). https://doi.org/10.3390/nu9101063

59. Schwingshackl L, Hoffmann G. Mediterranean dietary pattern, inflammation and endothelial function: a systematic review and meta-analysis of intervention trials. Nutr Metab Cardiovasc Dis. 2014;24(9):929-39.

60. Hoffmann G, Schwingshackl L. Mediterranean diet supplemented with extra virgin olive oil reduces the incidence of invasive breast cancer in a randomised controlled trial. Evid Based Med. 2016;21(2):72.

61. Skouroliakou M, Grosomanidis D, Massara P, Kostara C, Papandreou P, Ntountaniotis D, Xepapadakis G. Serum antioxidant capacity, biochemical profile and body composition of breast cancer survivors in a randomized Mediterranean dietary intervention study. Eur J Nutr. 2018:57(6):2133-45.

62. Enger SM, Ross RK, Paganini-Hill A, Carpenter CL, Bernstein L: Body size, physical activity, and breast cancer hormone receptor status: results from two case-control studies. Cancer Epidemiol Biomarkers Prev. 2000;9(7):681-687.

63. Rosenberg LU, Einarsdottir K, Friman El, Wedren S, Dickman PW, Hall P, Magnusson C: Risk factors for hormone receptor-defined breast cancer in postmenopausal women. Cancer Epidemiol Biomarkers Prev. 2006;15(12): 2482-2488.

64. Suzuki R, Rylander-Rudqvist T, Ye W, Saji S, Wolk A: Body weight and postmenopausal breast cancer risk defined by estrogen and progesterone receptor status among Swedish women: A prospective cohort study. Int J Cancer 2006;119(7):1683-1689.

65. Undela K, Srikanth V, Bansal D: Statin use and risk of breast cancer: a metaanalysis of observational studies. Breast Cancer Res Treat 2012, 135(1):261-269.

66. Mansourian M, Haghjooy-Javanmard S, Eshraghi A, Vaseghi G, Hayatshahi A, Thomas J: Statins Use and Risk of Breast Cancer Recurrence and Death: A Systematic Review and Meta-Analysis of Observational Studies. J Pharm Pharm Sci 2016, 19(1):72-81. 